\title{
Strategi Peningkatan Kemampuan Bicara Anak Usia 3 Tahun Melalui Youtube
}

\author{
Siti Rakiyah \\ Universitas Quality Medan, Jl. Ngumban Surbakti No.18, Sempakata, Kec. Medan Selayang, Kota Medan, \\ Sumatera Utara 20132. Indonesia. \\ e-mail : sitirakiyah09@gmail.com
}

Received : 28-06-2021, Revision : 02-07-2021, Acceptance : 02-07-2021, Published Online : 02-07-2021

\begin{abstract}
ABSTRAK
Beragam media yang dapat digunakan dalam pembelajaran dalam meningkatkan kemampuan bicara anak, salah satunya adalah Youtube. Penelitian ini bertujuan untuk mengetahui sejauh mana media YouTube mampu membentuk kecakapan atau keterampilan berbicara pada seorang anak yang berusia 3 tahun. Penelitian ini adalah penelitian deskriptif kualitatif. Subjek penelitian adalah satu orang anak berusia 3 tahun. Pengumpulan data dalam penelitian ini dilakukan dengan metode pengamatan, wawancara, dan catatan lapangan. Hasil penelitian menunjukkan bahwa adanya pengaruh dalam keterampilan berbicara anak usia 3 tahun yang dikarenakan media Youtube berupa video kartun. Hal ini dapat dilihat dari adanya ketertarikan subjek ketika menonton video-video kartun. Youtube juga dipandang sebagai media pembelajaran dalam pemerolehan bahasa bagi anak, namun sisi lain peran yang tidak kalah penting yaitu interaksi orang tua menstimulasi daya nalar komunikasi anak tersebut. Hal ini lah yang membantu anak menyerap apa yang dilihatnya pada youtube kepada orang tua maupun orang di sekitarnya. Sehingga dapat diambil kesimpulan bahwa media Youtube memberikan kontribusi keterampilan berbicara pada anak berusia 3 tahun.
\end{abstract}

Kata kunci: Bicara; Membaca; Anak Usia Dini; Youtube

\begin{abstract}
There are many media that can be used in learning to improve children's speaking skills, one of which is Youtube. This study aims to determine the effect of YouTube media on speaking skills of 3 year olds. This research is a qualitative descriptive study. The research subject was a 3 year old child. Data collection in this study was carried out by means of observation, interviews, and field notes. The results showed that there was an influence on the speaking skills of 3 year olds due to Youtube media in the form of cartoon videos. This can be seen from the subject's interest when watching cartoon videos. Youtube is also seen as a learning medium in language acquisition for children, but the other side that is no less important is the interaction of parents who stimulate children's communication reasoning power. This is what helps children absorb what they see on YouTube to their parents and those around them. So it can be concluded that Youtube media contributes to speaking skills in children aged 3 years.
\end{abstract}

Keywords: Speaking; Reading; Young Learners; Youtube 


\section{LATAR BELAKANG}

Masa keemasan anak yaitu saat berada pada masa keemasan (golden age). Pada masa inilah orang tua maupun lingkungan turut berperan membantu tumbuh kembang anak secara optimal. Banyak cara yang dapat digunakan untuk menstimulasi pertumbuhan dan perkembangan anak mulai dari perkembangan kognitif, bahasa, fisik motorik, emosional, moral, spiritual hingga seni (Fika et al., 2019).

Undang-Undang Nomor 20 tahun 2003 bab I pasal I ayat 14 tentang sistem pendidikan nasional menyatakan bahwa pendidikan anak usia dini adalah suatu upaya pembinaan yang ditujukan kepada anak sejak lahir sampai dengan usia enam tahun yang dilakukan melalui pemberian rangsangan pendidikan untuk membantu pertumbuhan dan perkembangan jasmani dan rohani agar anak memiliki kesiapan dalam memasuki pendidikan lebih lanjut (Undang-Undang Republik Indonesia Nomor 20 Tahun 2003, 2). Perkembangan kemampuan berbicara pada anak dapat dilatih dengan beragam stimulus diantaranya penggunaan media pembelajaran yang dikemas dalam berbagai bentuk seperti media gambar (visualisasi), suara (audio) dan lainnya (Aprinawati, 2017). Media juga dapat menjadi pengantar suatu pesan dan membuatnya terlihat lebih mudah dipahami. Kemunculan teknologi media pembelajaran saat ini tentunya dapat memotivasi anak-anak untuk lebih mudah mengenal berbagai pengetahuan bahasa (kosakata) yang dihasilkan oleh media audio visual salah satunya youtube.

Youtube merupakan situs yang sangat populer pada saat ini yang mampu dimanfaatkan dalam pendidikan. Keunggulan youtube dalam pendidikan yaitu penggunaanya sangat praktis yang mudah digunakan dan diikuti oleh peserta didik dan guru, youtube memberikan informasi mengenai perkembangan ilmu di berbagai bidang pendidikan serta youtube menawarkan fasilitas interaktif untuk berdiskusi. Nunan menyatakan bahwa kosakata merupakan hal penting agar dapat menggunakan bahasa kedua (second languange). Tanpa kosakata yang luas, seseorang tidak mampu menggunakan struktur dan fungsi bahasa dalam komunikasi secara konfrehensif. Tarigan menyatakan bahwa kualitas berbahasa seseorang tergantung pada kualitas kosakata yang dimiliki. Makin banyak kosakata yang dimiliki, semakin besar pula kemungkinan terampil berbahasa (Mardika, 2008).

Dari penjelasan di atas maka dapat dikatakan bahwa kosakata adalah kata-kata yang dimiliki suatu bahasa atau seseorang yang membentuk bahasa yang bersangkutan atau dipakai oleh orang atau kelompok anak yang bersangkutan. Kosakata juga dapat diartikan sebagai himpunan kata yang diketahui oleh seorang atau merupakan bagian dari suatu bahasa tertentu. Menurut Kamus Besar Bahasa Indonesia, kosakata adalah perbendaharaan kata. 
Pengetahuan tentang kosakata merupakan pusat keahlian dalam berbahasa. Oleh karena itu, pembelajaran kosakata merupakan sesuatu yang sangat penting. Dalam pembelajaran kosakata diperlukan adanya sebuah prosedur dan pendekatan. Pembelajaran kosakata dalam hal ini menyangkut mengajar dan belajar kosakata (Mardika, 2008).

Kemampuan bahasa anak usia dini berada dalam fase perkembangan diantaranya perkembangan bahasa. Bahasa sebagai sarana komunikasi yang mewakili symbol pikiran dan perasaan untuk menyampaikan makna kepada orang lain. Melalui bahasa, anak dapat belajar mengungkapkan berbagai bentuk perasaan dalam hatinya sehingga orang lain mengetahui apa yang dirasakan oleh anak. Menurut Sunarto dan Agung Hartono, perkembangan bahasa anak dipengaruhi oleh beberapa faktor yaitu umur anak, kondisi lingkungan, kecerdasan anak, status sosial ekonomi dan kondisi fisik. Berbagai hasil penelitian menunjukkan bahwa usia dini merupakan masa peka yang sangat penting bagi pendidikan anak, masa ini memerlukan rangsangan dan stimulasi yang tepat supaya kemampuan anak berkembang optimal, termasuk kemampuan berbahasa (Aprinawati, 2017).

Anak usia dini ialah individu yang sedang mengalami proses pertumbuhan dan perkembangan yang sangat pesat, bahkan dikatakan sebagai lompatan perkembangan. Anak usia dini memiliki rentang usia yang sangat berharga dibandingkan usia-usia selanjutnya karena perkembangan kecerdasan yang sangat luar biasa. Pemerintah melalui UU Sisdiknas mendifinisikan anak usia dini adalah anak dengan rentang usia 0-6 tahun. Soemiarti mengutip pendapat tentang anak usia dini menurut Biecheler dan Snowman, yang dimaksud anak prasekolah adalah mereka yang berusia antara 3-6 tahun (Patmonodewo, 2020).

Pada fase ini anak mengalami perubahan pertumbuhan dan perkembangan baik secara aspek jasmani maupun rohaninya yang berlangsung seumur hidup, bertahap dan berkesinambungan. Anak usia dini berada dalam proses perkembangan sebagai perubahan yang dialami oleh setiap manusia secara individual dan berlangsung sepanjang hayat mulai dari masa konsepsi hingga meninggal. Kemampuan bahasa ini juga yang membantu anak berkomunikasi dengan orang lain, anak telah dapat mengungkapkan keinginannya, penolakannya, maupun pendapatnya dengan menggunakan bahasa lisan sebagai alat berkomunikasi. Anak usia dini dapat mengucapkan kata-kata yang mereka gunakan, dapat menggabungkan beberapa kata menjadi kalimat yang berarti.

Di sisi lain, banyak juga kekhawatiran lain yang membuat keraguan apakah pembelajaran bahasa menggunakan media youtube efektif dalam meningkatkan kemampuan berbahasa pada anak balita, atau justru memiliki dampak lain yang justru sebaliknya menggangu kemampuan berbicara pada anak tersebut seperti Speech Delay atau 
keterlambatan bicara merupakan istilah umum merujuk pada proses keterlambatan bicara dan berbahasa yang tidak sesuai dengan usia perkembangan anak. Beberapa orang tua menganggap speech delay sebagai kondisi normal atau hal yang biasa dialami dalam proses tumbuh kembang anak (Kurniati \& Nuryani, 2020).

Gejala speech delay atau keterlambatan bicara harus menjadi perhatian serius bagi orang tua, sehingga mampu mengatasinya. Kurangnya pemahaman dan perhatian serius dari orang tua mengenai kondisi speech delay pada anak dapat mengganggu proses tumbuh kembang anak di tahap selanjutnya. Menurutnya, orang tua perlu mendeteksi sedini mungkin pada saat usia 12-13 bulan dan pada umur itu setidaknya anak mengucapkan tambahan satu sampai dua kata selain ma-ma atau da-da. Speech delay pada anak merupakan suatu gangguan yang perlu diperhatikan, hal ini bukan sebuah diagnosa melainkan sebuah gejala, jadi pada anak dengan speech delay itu adalah gejala awal dari beberapa macam gangguan. Penulis akan mengulas persoalan ini berdasarkan hasil penelitian yang dilakukan terhadap anak berusia 3 tahun, hal ini penting untuk memahami efektifitas pembelajaran bahasa melalui media pembelajaran menggunakan youtube dan dampaknya terhadap kemampuan berbicara anak usia dini.

\section{TINJAUAN PUSTAKA}

\section{Perkembangan Bahasa Anak Usia Dini}

Anak usia dini memiliki karakteristik yang khas, baik secara fisik, sosial, moral dan sebagainya. Menurut Siti Aisyah, dkk, karakteristik anak usia dini antara lain yaitu memiliki rasa ingin tahu yang besar, merupakan pribadi yang unik, suka berfantasi dan berimajinasi,masa paling potensial untuk belajar, menunjukkan sikap egosentris, memiliki rentang daya konsentrasi yang pendek. Perkembangan sosial, anak mulai ingin melepaskan diri dari orangtuanya. Anak sering bermain di luar rumah bergaul dengan teman sebayanya, anak mulai menyukai permainan yang melibatkan banyak orang dengan saling berinteraksi (Di et al., n.d.).

Perkembangan bahasa seorang anak diharapkan dapat memenuhi kemampuan yang berhubungan dengan :

a. Pemahaman kemampuan memahami makna ucapan orang lain.

b. Pengembangan perbendaharaan kata, berkembangnya kemampuan anak untuk berkomunikasi dengan orang lain diharapkan dapat menambah perbendaharaan katanya. 
c. Menyusun kata-kata menjadi kalimat, semakin banyak perbendaharaan kata yang dimiliki anak, diharapkan ia mampu menyusun kata-kata tersebut dalam kalimat-kalimat sederhana.

d. Ucapan dengan bertambahnya usia dan melalui proses belajar menirukan dan mencontoh oarang lain disekitarnya, anak akan mampu mengucapkan dengan benar dan jelas lafal kata-kata tertentu yang pada mulanya dirasakan sulit.

\section{Aspek-aspek keterampilan Berbicara Anak Usia Dini}

Untuk mengembangkan keterampilan berbicara terdapat beberapa aspek kegiatan keterampilan bebicara. Kemampuan berbahasa anak harus dioptimalkan diberdasarkan aspek yang mendukung peningkatan keterampilan berbicara. Dalam pengoptimalkan keterampilan berbicara perlu instrumen untuk mengamati perkembangan anak usia dini khususnya yang berusia 3 tahun, mengacu pada indikator yang ingin dikembangkan. Kemampuan mengucapkan, penguasaan kosakata dan pengenalan kalimat sederhana perlu dikembangkan instrumen untuk menilai, sehingga tampak jelas mengenai tingkat kemampuan bahasa anak (Harun Rasyid, Mansyur \& Suratno, 2009). Aspek yang dapat dilakukan dengan merangsang minat keterampilan berbicara, latihan menggabungkan bunyi bahasa, memperkaya perbedaharaan kata, mengenalkan kalimat melalui cerita dan nyayian, dan mengenalkan lambang tulisan (Suhartono, 2005). Dari kedua pendapat tersebut dapat diambil beberapa poin untuk mewakili penilaian perkembangan keterampilan berbicara anak antara lain : a). minat anak berbicara, b). kaya kata (kosakata), c). pengucapan lafal, d). pengenalan kalimat sederhana.

\section{METODE PENELITIAN}

Metode yang digunakan dalam penelitian adalah metode kualitatif deskriptif, yang menitikberatkan pada aspek naturalistik terhadap subjek penelitian. Metode ini lebih peka dan lebih dapat menyesuaikan diri dengan banyak penajaman pengaruh bersama dan terhadap pola-pola nilai yang dihadapi. Metode ini diambil karena bekerja secara induktif atau bottomup (Bachri, 2010) yang sesuai dengan kepentingan dari penulis untuk menarik kesimpulan atas dasar pengamatan atas permasalahan yang diangkat terhadap seorang anak usia dini.

Penelitian ini dilakukan dengan mengamati seorang anak berusia 3 tahun yang juga merupakan orang terdekat dari peneliti sehingga mudah untuk mengamatinya. Penelitian ini berusaha memperlihatkan hasil dari suatu pengumpulan data kualitatif dengan apa adanya, tanpa dihitung atau dilihat hubungannya dengan perlakuan atau variabel lain. Observasi dilakukan untuk melihat dinamika yang melibatkan subjek penelitian, agar dapat menarik 
kesimpulan berdasarkan tujuan dari penelitian ini yaitu melihat pengaruh platform youtube membentuk kemampuan berbicara pada seorang anak berusia 3 tahun.

Peneliti juga mencatat berbagai kejadian melalui tahapan dokumentasi dan rekaman percakapan yang diucapkan oleh anak tersebut. penelitian deskriptif murni tidak diperlukan kelompok kontrol sebagai pembanding sebab yang dicari adalah prevalensi fenomena tertentu, atau untuk mendapatkan gambaran tentang hal-hal yang berkaitan dengan suatu fenomena. Analisis data dilakukan dengan melakukan pencatatan data, kategorisasi dan penarikan kesimpulan atas pemaknaan yang dilakukan atas data.

\section{HASIL DAN PEMBAHASAN}

Data yang diperoleh dari orang tua subjek yang diteliti bahwa anaknya yang berusia 3 tahun yang bernama Douhan (D) dengan sering menonton video kartun dari youtube mampu berkomunikasi dua arah dan dapat merespon setiap pertanyaan yang ditanyakan oleh ibu, kakek, bibi, paman, dan sepupu yang seusianya. Adapun pertanyaan yang diresponnya antara lain sebagai berikut:

a. Ibu

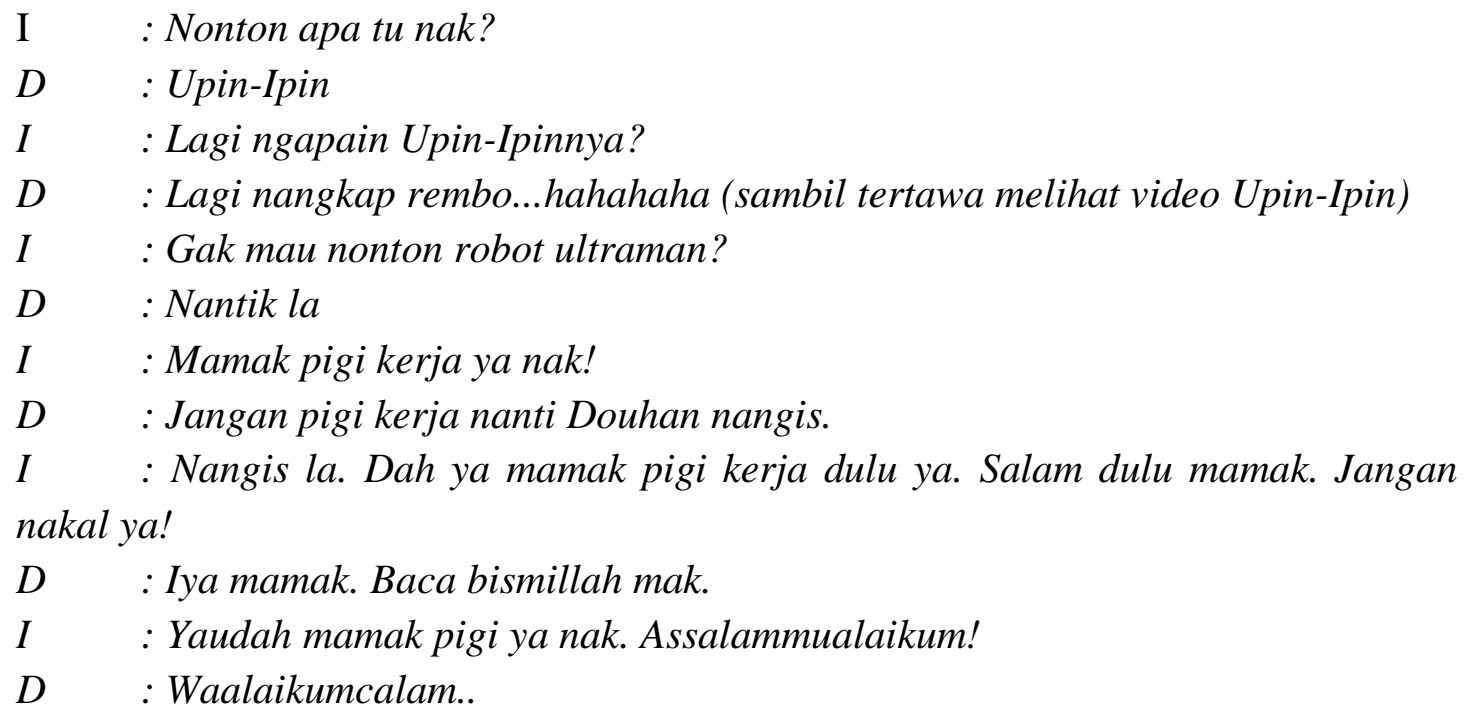

b. Kakek
K : Wak Ninak ada yang maen $h p$ !
D : Lagi makan lo
$K \quad$ : Tapi nanti siap makan hp nya dibalekin ya?
D $\quad$ : Iya
K : Kakek boleh pinjam?
D : Gak boleh ini untuk anak-anak.
$K \quad$ : Lagi nonton apa bang?
D $\quad$ : Robot ultraman. Lagi berantam orang ni kek. Ciat..ciat..

c. Bibi 


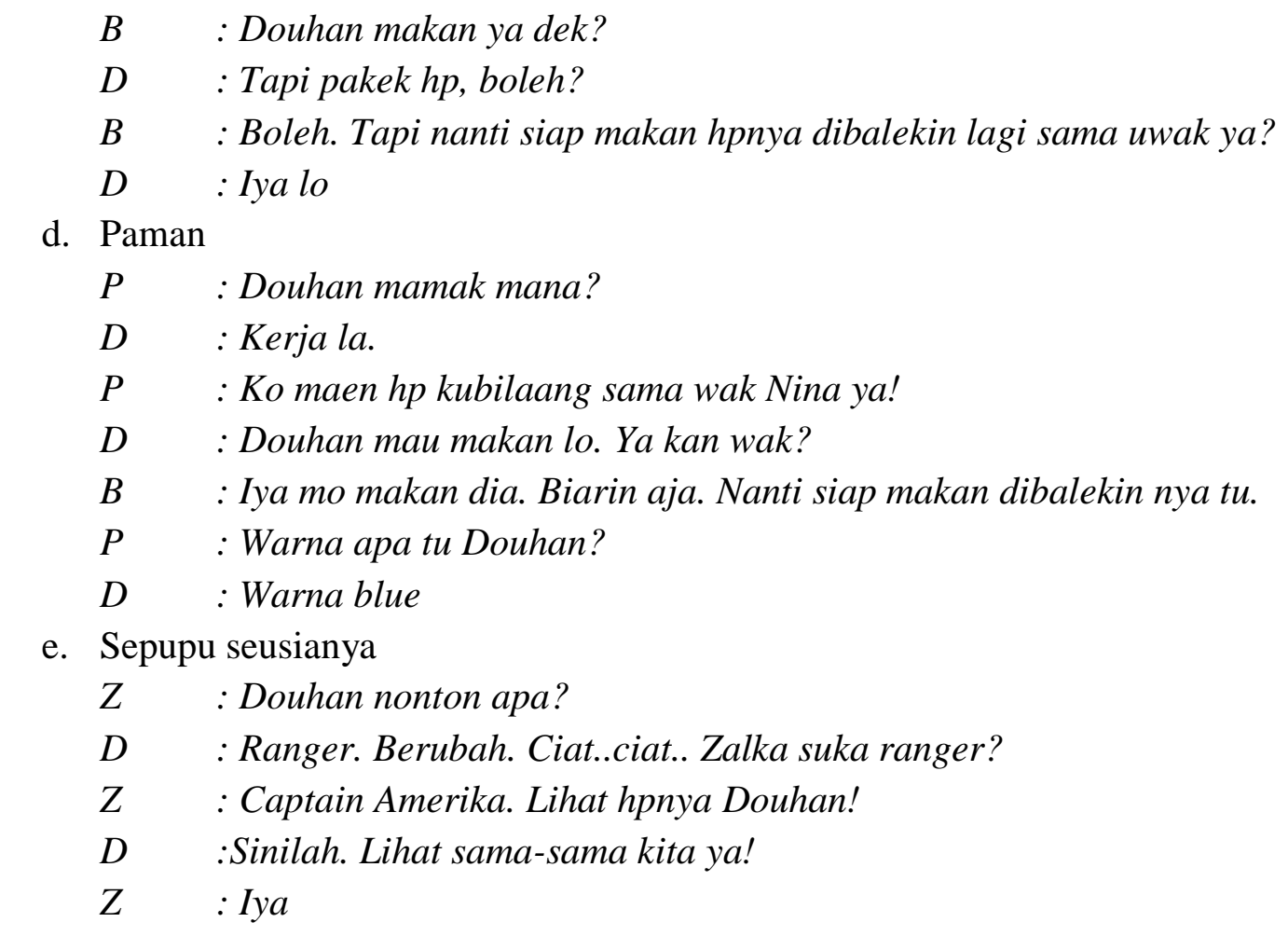

Hal yang paling menonjol dan berkembang pesat dalam stimulasi video youtube bagi anak yang diteliti adalah dalam hal bahasa dan imajinasi. Hal yang menarik dalam perkembangan imajinasinya adalah cara anak mengintepretasikan lingkunganya sesuai imajinasi dari apa yang terdapat pada isi video yang diberikan. Hal ini tentunya tidak terlepas dari usia anak yang saat itu berada dalam tahap meniru lingkungan, sehingga stimulasi dari video berbasis bahasa Inggris, lagu-lagu dan doa dapat direkam anak dengan baik dalam ingatannya. Tingkah anak yang aktif disini dapat dikatakan merupakan potensi kecerdasan kinestetik yang akan berkembang pada anak tersebut. Selain itu subjek menunjukan kecenderungan perkembangan dalam pengenalan warna. Sedangkan peran orang tua adalah dengan memberikan batasan kepada anaknya dalam penggunaan youtube karena youtube bukan stimulus utama dalam mengembangkan kemampuan berbicara anak.

Hasil penelitian yang telah dilakukan oleh Lestari didapatkan simpulan bahwa pada anak usia 3 tahun seharusnya telah memiliki kesadaran fonologis terutama pada keterampilan pemenggalan suku kata. Pada keterampilan tersebut anak usia 3 tahun masih dipengaruhi oleh kemampuan pelafalan fonem seperti fonem /r/. Meskipun demikian, tidak dapat dikatakan juga bahwa anak usia 3 tahun yang belum memiliki kesadaran fonologis dikategorikan sebagai anak yang mengalami keterlambatan bicara (Kurniati \& Nuryani, 2020). Sejak anak berusia 2 tahun perkembangan pemerolehan bahasa juga semakin baik terlihat dari bahasa yang diproduksi termasuk kalimat. Kalimat yang dihasilkannya termasuk kalimat yang 
lengkap dan sudah dapat dimengerti dengan cukup mudah, pengucapan fonemnya juga sudah cukup jelas (Lies Aryanti Nur Sholekah \& Agus Nuryatim, 2017).

Dalam kasus subjek penelitian pada anak yang diteliti berusia 3 tahun, mampu menjelaskan berbagai adegan peristiwa yang terdapat pada animasi kartun yang ditontonnya. Hal ini sejalan dengan pendapat yang dikemukakan oleh Hamied (1989: 24-30) bahwa faktor yang berpengaruh dalam proses pemerolehan dan pembelajaran bahasa pertama selain faktor eksternal juga faktor internal. Faktor eksternal meliputi faktor sosial meliputi interaksi yang diperoleh dengan keluarga inti seperti ayah ibu kakak dan adik, sedangkan faktor internal mancakupi faktor transfer serapan bahasa ke otak melalui unsur kognitif (Rosi Wulandari, 2020). Faktor lain yang membantu perkembangan fonologi anak-anak yaitu pemusatan perhatian pada sekumpulan bunyi-bunyi yang didengarkan melalui tontonan animasi youtube pada anak tersebut. Kemudian hubungan antara produksi ucapan si anak (representasi fonetiknya) dengan kata yang coba diucapkan oleh anak tersebut. Jika seorang anak telah mengucapkan suatu kata dalam situasi komunikasi tertentu dan dapat dipahami oleh lingkungannya sebagai lawan komunikasinya, maka dapat disimpulkan bahwa anak tersebut telah menguasai bunyi bahasa tersebut.

Berkaitan dengan aspek negative yang dikhawatirkan timbul pada anak usia dini mengkonsumsi media youtube yang dapat menyebabkan speech delay, ternyata tidak serta merta disebabkan karena konsumsi youtube. Justru sebaliknya kesadaran berkomunikasi dan mendengar yang baik diperoleh oleh si anak yang penulis teliti. Begitu banyak stimuluS positif yang justru dapat diambil oleh si anak melalui berbagai tayangan animasi kartun yang ditontonnya. Penelitian yang dilakukan pada anak yang mengalami speech delay, bahwa media sosial media Youtube memiliki pengaruh yang signifikan terhadap pemerolehan bahasa anak usia 3-4 tahun. Demikian juga pada anak yang mengalami speech delay. Media sosial youtube dapat digunakan sebagai media untuk membantu anak-anak yang mengalami keterlambatan bicara untuk mengenalkan kosa kata (Kurniati \& Nuryani, 2020). Peran serta lingkungan terdekat seperti orang tua juga sangat penting, dengan membiasakan interaksi dengan si anak maka kemampuan nalar, dan otot berbicara si anak juga terlatih. Si anak tidak dibiarkan hanya diam menonton selama berjam-jam sendirian yang justru dapat mengganggu otot syaraf bicara pada anak usia dini.

\section{Dampak Positif dan Negatif Anak Usia Dini Nonton Youtube}

Youtube adalah database video yang paling populer di dunia internet, atau bahkan mungkin yang paling lengkap dan variatif. Saat ini Youtube menjadi situs online Video 
provider paling dominan di dunia. Youtube kini telah menjadi berbagai macam kebutuhan dari penggunanya, fiturfitur yang ditawarkan dengan kemajuan teknologi Youtube saat ini sangat membantu dari berbagai aspek kebutuhan yang dibutuhkan sang pengguna. Youtube mempunyai pengertian sebagai situs media digital (video) yang dapat di download, diunggah, serta dibagikan (share) di seluruh penjuru negeri (Baskoro, 2009).

Youtube merupakan situs sosial media yang sering dipakai serta fenomenal di kalangan masyarakat. Masyarakat menggunakan youtube baik dalam melihat berita terkini, mencari informasi, bahkan untuk hiburan seperti menonton film, mendengarkan lagu atau menonton berbagai tutorial. Youtube ialah sebuah basis data berisi konten video yang popular di media sosial serta penyedia beragam informasi yang sangat membantu (Sianipar, 2013). Youtube mempunyai fungsi untuk mencari suatu informasi video atau melihat video secara langsung. Youtube dirancang sebagai situs berbagi video yang sangat populer terutama dikalangan generasi muda dan bahkan youtube sebagai situs untuk berbagi informasi di era digital saat ini. Generasi muda hampir sebagian besar menggunakan youtube dalam kehidupan sehari-hari mereka.

Saat ini Youtube mulai jadi media tontonan wajib semua golongan termasuk anakanak karena youtube lebih fleksibel tanpa nunggu jadwal tayang yang harus ditungguin kalau nonton di channel TV. Dan ini lah yang membuat kebanyakan anak-anak lebih memilih nonton kartun di youtube daripada nunggu pagi-pagi di depan TV. Selain soal waktu, tentu anak-anak juga lebih mudah memilih kartun yang mereka suka untuk ditonton. Bebas pilih juga episode berapapun dan lainnya. Tetapi sebagai orangtua atau orang dewasa, ini bisa jadi pekerjaan tersendiri dengan adanya layanan youtube ini. Di satu sisi youtube punya dampak positif, namun jika tidak diatur dengan baik, akan menjadi dampak negatif untuk anak-anak. Disinilah peran orang dewasa untuk lebih bijak dalam memberikan akses youtube kepada anak-anaknya agar terhindar dari dampak negatif dari youtube itu sendiri.

Adapun dampak positif anak-anak menonton tayangan di youtube adalah sebagai berikut:

a. Sebagai media belajar

b. Membuat anak berpikir kreatif

c. Menghilangkan rasa bosan

Adapun dampak negatif anak-anak menonton tayangan di youtube adalah sebagai berikut:

a. Membuat anak kurang disiplin

b. Menonton video tidak sesuai umur 
c. Mengabaikan tugas sekolah bahkan mengabaikan panggilan orang tua atau orang disekitar.

\section{KESIMPULAN}

Hasil data yang diperoleh dapat diketahui bahwa dalam penggunaan youtube dapat membantu para orang tua dalam meningkatkan kemampuan berbicara anak-anak usia dini. Karena dari video yang ditontonkan dari youtube dapat merangsang atau menstimulus anak untuk meniru setiap kata yang diutarakan dalam tokoh yang di dalam video tersebut. Selain itu di youtube anak-anak bisa dengan mudah memilih jenis kartun atau tontonan yang akan dilihat oleh mereka dan juga tampilan video yang dihasilkan sangat menarik sehingga setiap anak yang menonton tayangan video kartun di youtube pasti akan menyukai tayangan tersebut.

Sebagaimana yang kita ketahui sebelumnya bahwa youtube dapat membantu para orang tua dalam meningkatkan kemampuan berbicara anak-anak usia dini, tapi itu bukanlah stimulus yang paling utama yang harus dilakukan orang tua. Dalam hal ini orang tua mempunyai peranan penting dalam membantu meningkatkan kemampuan berbicara anak misalnya dengan sering melakukan komunikasi yang intens kepada anaknya, membiarkan anak-anak untuk melakukan pergaulan dengan seusianya di lingkungan tempat tinggal, dan juga orang tua harus mendampingin anak-anaknya atau memberikan batasan pada video youtube tontonan anak-anak mereka.

\section{DAFTAR PUSTAKA}

Aprinawati, I. (2017). Penggunaan Media Gambar Seri Untuk Meningkatkan Kemampuan Berbicara Anak Usia Dini. Jurnal Obsesi : Jurnal Pendidikan Anak Usia Dini, 1(1), 72. https://doi.org/10.31004/obsesi.v1i1.33

Bachri, B. S. (2010). Meyakinkan Validitas Data Melalui Triangulasi Pada Penelitian Kualitatif. Teknologi Pendidikan, 10, 46-62.

Baskoro, A.(2009). Panduan Praktis Searching di Internet. Jakarta : PT Trans Media

Bungin, Burhan. (2015). Metodologi Penelitian Kuantitatif: Komunikasi, Ekonomi, dan Kebijakan Publik Serta Ilmu-ilmu Sosial lainnya. Jakarta: Kencana Prenada

Daryanto. 2013. Media Pembelajaran. Yogyakarta, Gava Media.

Di, I., Garut, K., Siti, O., Kartika, R., Marlina, N. C., Si, M., K, A. W., \& Sos, S. (n.d.). Makna YouTube Bagi Seorang Ibu (Studi Fenomenologi Tentang Makna Penggunaan YouTube Pada Anak Usia Dini Bagi Seorang Ibu.

Fika, Y., Meilanie, S. M., \& Fridani, L. (2019). Peningkatan Kemampuan Bicara Anak 
melalui Bermain Peran Berbasis Budaya. Jurnal Obsesi : Jurnal Pendidikan Anak Usia Dini, 4(1), 50. https://doi.org/10.31004/obsesi.v4i1.229

Kurniati, M., \& Nuryani, N. (2020). Pengaruh Sosial Media Youtube Terhadap Pemerolehan Bahasa Anak Usia 3-4 Tahun (Studi Pada Anak Speech Delay). Fon : Jurnal Pendidikan Bahasa Dan Sastra Indonesia, 16(1), 29. https://doi.org/10.25134/fjpbsi.v16i1.2494

Lies Aryanti Nur Sholekah \& Agus Nuryatim. (2017). Jurnal Pendidikan Bahasa dan Sastra Indonesia. Jurnal Pendidikan Bahasa Dan Sastra Indonesia, 1(budaya literasi dalam pembelajaran bahasa), $12-16$. https://journal.unnes.ac.id/sju/index.php/jpbsi/article/view/20226

Mardika, I. N. (2008). Pengembangan Multimedia Dalam Pembelajaran Kosakata Bahasa Inggris Di SD. ... . Tripod. Com/Multimedia. Pdf [16 Juni 2012], 4, 1-23. http://mardikanyom.tripod.com/Multimedia.pdf

Nuraeni. 2009. "Penerapan Teknik Cerita Berantai Untuk Meningkatkan Kemampuan Berbicara Siswa", Dalam http://tarmizi.wordpress.com/

Patmonodewo, S. (2000). Pendidikan anak prasekolah. Rineka Cipta bekerjasama dengan Departemen Pendidikan \& Kebudayaan.

Rosi Wulandari, G. (2020). Pemerolehan Bahasa: Kajian Aspek Fonologi Pada Anak Usia 22,3 Tahun. Imajeri: Jurnal Pendidikan Bahasa Dan Sastra Indonesia, 2(2), 129-136. https://doi.org/10.22236/imajeri.v2i2.5084

Rukajat, A. (2018). Pendekatan Penelitian Kualitatif (Qualitative Research Approach). Deepublish.

Sianipar, A. P. (2013). Pemanfaatan youtube di kalangan mahasiswa. Jurnal Ilmu Komunikasi FLOW, 2(3), 1-10. Retrieved from https://jurnal.usu.ac.id/index.php/flow/article/view/9930/4418

Soemiatri. 2000. Pendidikan Anak Prasekolah. Rineka Cipta: Jakarta

Suharyanti dan Edy Suryanto. 1996. Reorika: Buku Pegangan Kuliah. Surakarta: UNS Press. Undang-Undang Republik Indonesia Nomor 20 Tahun 2003. Tentang Sistem Pendidikan Nasional (Jakarta: CV, Medya Jakarta) 